\title{
Sosyal Dışlanma Olgusu Üzerine Genel Bir İnceleme ${ }^{a}$
}

\author{
Çağlar Solak ${ }^{b, c}$, Mert Teközel ${ }^{\mathrm{d}}$
}

\section{Özet}

Sosyal bir tür olan insan, gruplar içerisine doğmakta ve belli grupların üyesi olarak yaşamını sürdürmektedir. Bu nedenle sosyal ilişkilere kabul edilmek ve gruplarda yer almak, tüm kültürlerde gözlemlenen temel bir motivasyon ve ihtiyaçtır (Baumeister ve Leary, 1995). Öte yandan, diğerleri tarafından kabul görmemek ve ait olma ihtiyacının karşılanmaması sosyal yaşamda sıklıkla karşımıza çıan bir durumdur. Görmezden gelinme, yok sayılma, reddedilme kavramlarını içinde barındıran "sosyal dışlanma" bireylerin üzerinde bir dizi davranışsal, duygusal, bilişsel ve fizyolojik etkiye yol açmaktadır. Bu çalışmada, dışlanma olgusunu sosyal psikolojik açıdan ele alan araştırmalardan yola çıkılarak konuya dair kapsamlı bir inceleme sunmak amaçlanmıştır. Alandaki öncü çalışmalara ek olarak güncel literatür de göz önünde bulundurulmuş ve öncelikle dışlanma olgusu kavramsal ve tarihsel olarak ele alınmış, ardından deneysel çalışmalarda katılımcılara dışlanma deneyimi yaşatmak için kullanılan belli başlı yöntemlerden bahsedilmiş ve sosyal dışlanmanın bireyler üzerinde yarattığı etkiler ele alınmıştır. Son olarak dışlanma olgusunu açıklamaya çalışan teorik yaklaşımlardan söz edilmiştir.
Anahtar Kelimeler

Sosyal Dışlanma

Reddedilme

Ait Olma İhtiyacı

Kişiler Arası İlişkiler

Makale Hakkında

Geliş Tarihi: 01.07.2019

Kabul Tarihi: 20.11.2019

Doi: 10.18026/cbayarsos.585260

\section{A Comprehensive Examination of Social Exclusion}

\begin{abstract}
As a social species, people are born into groups and maintain to live as members of groups. Therefore, inclusion in groups is a basic need in all human cultures (Baumeister and Leary, 1995). On the other hand, rejection by others is a common experience in social life. Social exclusion, eliciting the sense of being ignored, feeling invisible and rejected, leads to a series of behavioral, emotional, cognitive and physiological effects on humans. In this article, it is aimed to present a comprehensive examination of the social exclusion phenomenon based on research from social psychology. Firstly, in addition to the earliest studies in the field, contemporary literature has been taken into consideration and the phenomenon of exclusion has been conceptually and historically discussed. Then, the common methods which were used to give participants an experience of exclusion in the laboratory conditions are mentioned. Finally, the effects of social exclusion on individuals and theoretical approaches that try to explain social exclusion were discussed.
\end{abstract}

Keywords

Social Exclusion

Rejection

Need to Belong

Interpersonal Relations

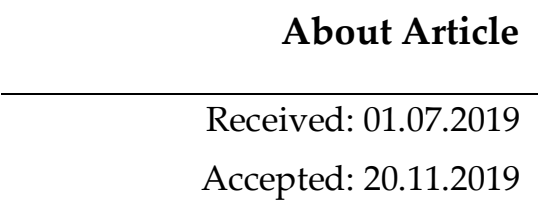

Doi: 10.18026/cbayarsos.585260

\footnotetext{
a Bu çalışma, Çağlar Solak'ın hazırladığı "Sosyal Dışlama ve Dâhil Olmanın Eşleşme Süreçlerindeki Etkilerinin Evrimsel Açıdan İncelenmesi” başlıklı yüksek lisans tezinden üretilmiştir.

b İletişim Yazarı: caglar.solak@cbu.edu.tr

c Araştırma Görevlisi Dr., Manisa Celal Bayar Üniversitesi, Fen Edebiyat Fakültesi, Psikoloji Bölümü, ORCID: 0000-0002-0421-8627

d Doç. Dr., Ege Üniversitesi, Edebiyat Fakültesi, Psikoloji Bölümü, ORCID: 0000-0002-2224-1425
} 


\section{Giriş}

Yeryüzünde varlığını sürdüren sayısız canlı türü gruplar halinde yaşamakta, korunma, beslenme gibi hayati problemlerin üstesinden iş birliği sayesinde gelmektedir (Schaller ve Neuberg, 2008). Pek çok alt türü sosyal bir yaşam biçimi geliştirmiş olan memelilerin bir üyesi olarak insanlar da milyonlarca yıldır gruplar halinde yaşamaktadırlar. İnsan türünün devamı için çözülmesi en önemli adaptif problemlerden olan besin kaynağı bulma, eş bulma ve üreme, yırtıcılardan korunma, avlanma, çocuk bakımı sağlama gibi problemlerle başa çıkmak grup içinde koordineli ve el birliğiyle hareket ederek çok daha kolay olmuştur (Boesch, 2012). Bu nedenle gruplara dâhil olmak ve sosyal ilişkilere kabul edilmek bireylerin hayatta kalma ve üreme başarılarının sürekliliği açısından olmazsa olmaz koşullardandır. Dolayısıyla, diğer pek çok psikolojik ihtiyaç gibi ait olma ihtiyacı (need to belong) da tüm kültürlerde ve insanlarda gözlemlenebilen evrensel bir ihtiyaçtır (Baumeister ve Leary, 1995). Sosyal dişlanma ise bu ihtiyacın yeterince karşılanmasını tehdit ederek bireyler üzerinde bir dizi olumsuz etkiye yol açmaktadır.

Son yirmi yıllık süreçte sosyal dışlanma konusuna yönelik ilgi ve deneysel araştırmaların sayısı giderek artmıştır. Olguyu farklı boyutlarıyla masaya yatıran araştırmacıların bir kısmı, grup üyelerinin diğer bir kişiyi neden ve hangi amaçla dışladıklarına odaklanmış (örn., Benenson, Hodgson, Heath ve Welch, 2008; Benenson, Markovits, Thompson ve Wrangham, 2011; Wesselmann, Wirth, Pryor, Reeder ve Williams, 2013), diğer bir kısmı ise gruptan dışlanmanın ve başkaları tarafından yok sayılmanın bireyler üzerinde doğurduğu sonuçları incelemiştir (örn., Gonsalkorale ve Williams, 2007; Hess ve Pickett, 2010; Moor, Crone ve van der Molen, 2010; Smith ve Williams, 2004; Stillman ve diğer., 2009). Çok sayıda deneysel çalışmada ortaya koyulmuştur ki sosyal dişlanma, bireylerin beyin aktiviteleri (Eisenberger, Liberman ve Williams, 2003), fizyolojik tepkileri (Ijzerman ve diğer., 2012; Zhong ve Leonardelli, 2008), dikkat süreçleri (DeWall, Maner ve Rouby, 2009), bellek performansları (Gardner, Pickett ve Brewer, 2000), mantık yürütme becerileri (Baumeister, Twenge ve Nuss, 2002), duygulanımları (DeWall ve Baumeister, 2006; Zadro, Williams ve Richardson, 2004), olumlu ve olumsuz sosyal davranışları (Lakin ve Chartrand, 2005; Van Beest, Williams ve Van Dijk, 2011) üzerinde güçlü etkilere sahiptir.

Burada dışlanma olgusu öncelikle kavramsal ve tarihsel açıdan ele alınacak, ardından bu olgunun deneysel olarak nasıl incelendiği ve sosyal dışlanmanın insanlar üzerindeki etkileri ile teorik yaklaşımlardan bahsedilecektir.

\section{Dişlanma Kavramı}

İnsan sosyalliğinin karmaşık labirentlerinde dolaşırken karşımıza neredeyse her köşe başında çıkan bir manzara vardır: Bireylerin bazı zamanlarda ve koşullarda birbirlerini reddedişi, görmezden gelişi ve hatta yok sayışı; yani birbirlerini sosyal açıdan dışlayışı. Dışlanma olgusu, günlük hayattaki en basit sosyal etkileşimlerden, uzun tarihsel dönemlerdeki toplumsal çatışmalara kadar, insan türünün gruplar halinde bir arada yaşadığı her yerde ve devirde sosyal hayatın kaçınılmaz bir parçası olmuştur. Bu olgunun bir ucunda dışlayanlar, diğer ucunda ise dişlananlar vardır ve neredeyse her birey hayatı boyunca bu iki uçta da zaman zaman yer almaktadır. Grup ve birey açısından sosyal dışlamanın amaçları ve getirileri, 
dişlanan kişilerinse bundan nasıl etkilendikleri ilerleyen sayfalarda bahsedeceğimiz pek çok araştırmanın konusu olmuştur. Konunun detaylarına geçmeden evvel, sosyal dışlanma dendiğinde tam olarak ne ifade edilmek isteniyor, bunu açıklamalıyız.

İlgili literatüre bakıldığında bireyin gruptan dışlanması, ihraç edilmesi, yok sayılması, dâhil edilmemesi veya reddedilmesi olgularını ifade etmek için temelde üç kavramın kullanıldığ görülmektedir: sosyal dışlama (social exclusion), psikolojik dışlama (ostracism) ve sosyal reddetme (social rejection). Bu üç ifade biçimi aslında aynı olgunun anlatımında kullanılsa da bazı araştırmacılar sosyal dışlama, psikolojik dışlama ve sosyal reddetme ifadeleri arasındaki kavramsal farklılıkları irdelemeye çalışmıştır (örn. Leary, 2005). Pek çok araştırmacı ise bu kavramların aynı olguya işaret ettiğini düşünerek bunları eş anlamlı olarak kullanmıştır (örn., Oaten, Williams, Jones ve Zadro, 2008; Williams, 2007).

Sosyal dışlanma kavramı, bireylerin diğerlerinden ayrı olması, her türlü sosyal etkileşimden mahrum bırakılması, izole edilmesi anlamlarına gelen daha geniş bir kavramsal çerçeveye sahiptir. Dışlama durumu, dişlanan birey ya da bireylere açıkça ifade edilebileceği gibi, sözlü veya davranışsal bir reddediş içermeden de gerçekleşebilir. Psikolojik dışlama kavramı ise daha özel bir dışlama biçimine işaret etmektedir. Psikolojik dışlamada, dışlanan bireye bu durum açıç̧a belirtilmemekte, olumsuz bir davranış ya da söz aracılığıyla dışlandığı bildirilmemektedir. Bunun yerine dışlanan kişi, diğer birey veya grup tarafından görmezden gelinmekte, yok sayılmakta, adeta "varlı̆̆g" kabul edilmemektedir. Son olarak, sosyal reddetme durumunun ayırt edici noktası ise dışlanan kişinin söz konusu grupta ya da ilişkide istenmediğinin -veya artık istenmediğinin- sözlü yahut fiziksel olarak açıkça belirtilmesidir (Williams, 2007; Williams ve Zadro, 2005; Williams, Forgas, von Hippel ve Zadro, 2005).

Sosyal dışlama, psikolojik dışlama ve sosyal reddetme kavramlarının yukarıda bahsettiğimiz farklılıklarına rağmen, araştırmacılar arasında bu kavramların işevuruk (operational) tanımları hakkında genel geçer bir kabul yoktur (Williams, 2007). İlgili literatürde bunlar çoğunlukla aynı olgudan bahsedilirken kullanılmaktadır (Wesselmann ve diğer., 2016; Riva ve Eck, 2016; Wesselmann ve Williams, 2017; kavramsal bir tartışma için bkz. Leary, 2005). Dolayısıyla bu metin boyunca, kişilerin diğer bir birey ya da grup tarafından sosyal kabul görmemesi ve yok sayılması olgusundan bahsederken "sosyal dişlanma" ya da sadece "dışlanma" ifadesi kullanılacaktır.

\section{Geçmişten Bugüne Sosyal Dişlanma Olgusu}

M.Ö. 5. yüzyıl Atina'sı incelendiğinde şöyle bir uygulamayla karşılaşılmaktadır: Kış ayları geldiğinde Atina vatandaşları agorada toplanmakta ve ostraka adını verdikleri, üzerine bir isim yazılmış çömlek parçalarını konsey ve yüksek mahkeme üyelerine teslim etmekteydi. Çömlek parçalarının üstüne ismi belli bir sayıdan fazla yazılan Atina vatandaşlarının, kenti güvenli bir şekilde terk etmesi sağlanmakta ve bu kişilerin 5 veya 10 yıl boyunca Atina'ya dönmesine izin verilmemekteydi. Bu uygulamaya "ostrakismos" deniyordu (Forsdyke, 2005; Lang, 1990).

Atina demokrasisinde halk, para ya da siyasi güç sayesinde kendisine karşı haksız uygulamalarda bulunan, zorbaca tutumlar sergileyen ya da toplumsal kurallara aykırı 
davranmakta ısrar eden hemşerilerini uzunca bir süreliğine toplum dışında tutabiliyor, bu "dışlama tehdidi" sayesinde hukuksuzlukların artmasını engelleyebiliyordu (örneğin, bu şekilde şehirden sürgün edilen bir erkeğin dişlanma sebebi, kendi kız kardeşiyle cinsel ilişki yaşamasıdır; bkz. Lang, 1990). Buna benzer bir uygulama Sicilyalılar arasında da vardı ve orada oylar zeytin ağacı yapraklarına yazılıyordu (Abbort, 1911; akt. Williams, 2001).

Tarihin her döneminde ve her toplumda sosyal dışlanmanın açık örneklerine sık sık rastlansa da sosyal psikologların bu olguyla ilgili araştırmalar yapmaları görece yakın tarihlidir. 1990'ların öncesinde sosyal dışlanma, az sayıda sosyal psikologun incelediği bir olguydu. Bu ilk örneklerde doğrudan sosyal dışlanma konusu ele alınmasa da bunun başka değişkenlerle ilişkilerinden bahsedilmiştir. Sözgelimi, sosyal psikoloji tarihindeki önemli teorilerden biri olan İhtiyaçlar Teorisi'nde Maslow (1954), bireylerin ihtiyaçlarını beş hiyerarşik basamakta toplamış, fizyolojik ihtiyaçlar ve güvenlik ihtiyaçlarının ardından aidiyet ihtiyaçlarının (bir gruba dâhil olma) geldiğini savunmuştur (akt. Bilgin, 2003). Bu teorinin ortaya çıkışına yakın tarihlerde, Schachter (1951) grup fikirlerinden sapmayla gruptan reddedilme arasindaki ilişkiyi, Dittes (1959) gruba kabul edilmeyle benlik saygısı (self-esteem) arasındaki ilişkiyi, Jackson ve Saltzstein (1957) ise gruba kabul edilmeyle uyma (konformite) arasındaki ilişkiyi incelemişlerdir. Sonraki yıllarda Snoek (1962) reddedilmenin biçimiyle gruba yönelik çekim arasındaki ilişkiyi; Geller, Goodstein, Silver ve Sternberg (1974) diğerleri tarafından görmezden gelinmenin birey üzerindeki etkilerini; Craighead, Kimball ve Rehak (1979) sosyal reddedilme ile duygusal ve fizyolojik uyarılma arasındaki ilişkiyi, Fenigstein (1979) ise kendilik bilinci (self-consciousness) yüksek ve düşük bireylerin bir gruptan reddedilmeye verdikleri tepkileri araştırmıştır.

Dışlanma olgusunu çeşitli boyutlarıyla açıklamaya çalışan daha kapsamlı ve güncel yaklaşımlara sonraki kısımlarda ayrıntılı olarak değinilecek, öncesinde ise dışlanma çalışmalarında kullanılan yöntemlerden ve dışlanmanın insanlar üzerindeki etkilerinden bahsedilecektir.

\section{Laboratuvarda Sosyal Dişlanma}

Sosyal dışlanma çalışmalarında katılımcılara dışlanma deneyimi yaşatmak amacıyla kullanılan pek çok deneysel paradigma mevcuttur. Bunların arasında yaygın olarak kullanılan üç paradigmanın üzerinde daha ayrıntılı duracağı: (1) sanal top oyunu (cyberball), (2) yalnız yaşam tahmini paradigması (life alone paradigm) ve (3) geçmişteki bir dışlanma deneyiminin hatırlanmasi.

\section{Sanal Top Oyunu}

Sosyal dışlanma araştırmalarında kullanılan ilk deneysel yöntemlerden biri olan top atma oyunu paradigmasının (Williams, 1997; akt. Williams, 2007) anlaşmalı katılımcılar gibi zahmetli taraflarından kurtulmak ve uygulamayı daha pratik hale getirmek amaciyla araştırmacılar Sanal Top Oyunu adlı paradigmayı geliştirmişlerdir (Williams, Cheung ve Choi, 2000; Williams ve Jarvis, 2006). Bu yöntem top atma oyununun bilgisayar ortamina aktarılmasıyla oluşturulmuştur. Katılımcı oyunu, sözde gerçek kişiler olduğu söylenen, fakat bilgisayar tarafından kontrol edilen oyuncularla birlikte oynamakta, tüm oyuncular bilgisayar 
ekranında çizgilerden oluşan insan figürleriyle temsil edilmektedir. Katılımcı kendisine gelen topu bilgisayar faresini kullanarak seçtiği bir oyuncuya atmakta, diğer oyuncuların topu kime ne sıklıkla atacağı ise deneyci tarafından önceden programlanmaktadır. Katılımcılara paravan öykü olarak, birbirlerine internet ağıyla bağlı bilgisayarlar aracıllğıyla gerçekleştirilecek bir grup deneyine katılacakları söylenmekte ve deneyin amacının zihinde görselleştirme becerilerini araştırmak olduğu belirtilmektedir. Dışlanma koşulundaki katılımcılara oyunun başında top iki kez atılmakta ve ardından bu katılımcılara oyun süresince bir daha top gelmemektedir. Dâhil olma koşulundaki katılımcılar ise diğer oyuncularla hemen hemen eşit oranda top almaktadırlar. Bu koşulların dışında araştırmanın amacına bağlı olarak farklı koşullar da yaratılabilmektedir (aşırı dâhil olma, vb.). Oyun genellikle 30-50 top atışıyla son bulmaktadir.

Bu paradigma, sosyal dışlanma çalışan araştırmacılar tarafından oldukça yaygın olarak kullanılmaktadır. Sanal top oyunu kullanılarak yapılan 120 çalışma üzerinde gerçekleştirilen bir meta-analizde bu paradigmanın dışlanma deneyimi yaşatmadaki etki büyüklügünün yüksek olduğu (ortalama d>|1.4|) görülmüştür (Hartgerink, van Beest, Wicherts ve Williams, 2015). Öte yandan bazı yazarlar sanal top oyununun, gerçek hayattaki dişlanma deneyimlerine benzerliğiyle ilgili olarak dış geçerliliğinin sorgulanması gerektiğini düşünmektedirler (Wirth, 2016).

\section{Yalnız Yaşam Tahmini}

Sosyal dışlanma çalışmalarında sıklıkla kullanılan bir diğer paradigma Yalnız Yaşam Tahmini paradigmasıdır (Baumeister, Twenge ve Nuss, 2002; Twenge, Baumeister, Tice ve Stucke, 2001). Bu yöntemde katılımcılara bir kişilik testi uygulanmakta ve bu testten aldığı sonuç atanmış olduğu deneysel koşula bağlı olarak bildirilmektedir. Kişilik testinin sonuçlarının bir kısmı gerçek sonuçlarken (dışa dönüklük/içe dönüklük), diğer kısmı dışlanma manipülasyonunu yaratmak amacına yönelik olarak sahtedir. Deneysel koşullardan biri olan kabul edilme/yüksek aidiyet (accepted/high belonging) koşulunda katılımcıya, yaşamı boyunca ödüllendirici ilişkiler geliştireceği, uzun ve istikrarlı bir evlilik yaşayacağı ve her zaman onu önemseyen arkadaşlara sahip olacağı şeklinde bir geribildirim verilmektedir. Reddedilme/düşük aidiyet (rejected/low belonging) koşulunda katılımcıya, hayatının geri kalanını yalnız geçireceği, şu anda ilişkileri ve arkadaşları olsa da yirmili yaşlarının ortalarından sonra bunların ondan uzaklaşacağı, olası birkaç evliliğinin kısa süreceği ve otuzlu yaşlarında devam etmeyeceği söylenmektedir. İlişkilerle veya sosyal dışlanmayla ilgisi olmayan bir negatif geribildirim vermek amacı taşıyan negatif geribildirim kontrol koşulunda ise katılımcıya, şu ana kadar pek fazla başına gelmemiş olsa da geri kalan hayatında yaralanmalar ve kazalar geçireceği bildirilmektedir.

\section{Geçmişteki Bir Dışlanma Deneyiminin Hatırlanması}

Bu paradigma katılımcının belleğindeki bir dışlanma anısının çağırılmasına dayanmaktadır ve bazı araştırmalarda sosyal dışlanmanın etkilerinin ortaya çıkarılmasında geçmişte yaşanmış bir dışlanma deneyiminin hatırlanmasının etkili olduğu görülmüştür (örn., Maner, DeWall, Baumeister ve Schaller, 2007; Pickett, Gardner ve Knowles, 2004; Sacco ve diğer., 2012). Bu yöntemde dışlanma koşulundaki katılımcılardan, kendilerini diğerleri tarafından 
dışlanmış ya da reddedilmiş hissettikleri bir anı yazmaları istenmektedir. Dâhil olma koşulundaki katılımcılar ise kendilerini diğerleri tarafından sosyal açıdan dâhil edilmiş ya da kabul edilmiş hissettikleri bir anı yazmaktadırlar. Son olarak kontrol koşulundaki katılımcılar deney gününden bir önceki gün ne yaptıklarını yazmaktadırlar. Katılımcılar, yaşadıkları deneyimi net bir şekilde hatırlamaları, bunu gözlerinde canlandırmaları ve olabildiğince ayrıntılı bir şekilde yazmaları konusunda teşvik edilmektedir.

Yukarıda bahsettiğimiz ve sosyal dışlanma literatüründe sıklıkla karşılaşılan paradigmalar dışında araştırmacılar tarafından pek çok değişik paradigma yaratılmıştır. Özellikle sosyal dışlanmanın çocuklar üzerindeki etkilerini inceleyen çalışmalarda gerek etik hassasiyet, gerekse çocukların bilişsel kapasitesine uygun yöntemler bulmak amacıyla yaratıcı ve farklı paradigmalar geliştirilmiştir (örn., Nesdale ve Lambert, 2008; Over ve Carpenter, 2009). Katılımcılara dışlanma temalı senaryo okutmak (Aydin, Graupmann, Fischer, Frey ve Fischer, 2011), internet üzerindeki sohbet odalarında dışlanma (Williams ve diğer., 2002; Donate ve diğer., 2017), kısa mesaj aracılığıyla dışlanma (Smith ve Williams, 2004), çevrimiçi dışlanma (ostracism online; Wolf ve diğer., 2015), beyin fırtınası (Abayhan ve diğer., 2009; Kaya, Yavuz, Abayhan, Şahin ve Aydın, 2008) ve dışlanmaya dair eşik altı uyaran sunumu (Sommer ve Baumeister, 2002), sosyal dişlanma çalışmalarında kullanılan diğer paradigmalardan birkaçıdır.

\section{Sosyal Dışlanmanın Ortaya Çıkardı̆̆ı Tepkiler}

Bireylerin dışlanmadan nasıl etkilendikleri pek çok farklı bağlamda ele alınmış ve bu konuda çok sayıda ampirik çalışma yapılmıştır. Söz konusu çalışmaların dışlanmanın etkilerini inceleyiş biçimleri göz önünde bulundurularak, sosyal dişlanmanın doğurduğu tepkiler üç başlık altında ele alınacaktır: (1) otomatik tepkiler, (2) kısa vadede ortaya çıkan tepkiler ve (3) uzun süreli dışlanmanın ortaya çıkardığı tepkiler.

\section{Otomatik Tepkiler}

Çeşitli ölçümlerle yapılan araştırmalar göstermektedir ki sosyal dışlanma deneyimi yaşayan bireylerin, o anda otomatik olarak verdikleri birtakım fizyolojik tepkiler bulunmaktadır. Söz konusu tepkileri incelemek amacıyla dışlanma sürecinde beynin hangi bölgelerinin bundan etkilendiğini araştıran bazı fMRI (functional magnetic resonance imaging) çalışmaları gerçekleştirilmiştir. Bu çalışmalarda (Eisenberger, Liberman ve Williams, 2003; Bolling, Pelphrey ve Wyk, 2016; Moor ve diğer., 2012), yukarıda bahsi geçen sosyal dışlanma paradigmalarından sanal top oyunu oynadıkları esnada katılımcıların beyin görüntüleri alınmış ve oyundan dışlanmanın etkileri incelenmiştir. Katılımcıların dışlanma esnasındaki fMRI verileriyle, dâhil olma esnasındaki verileri karşılaştırıldığında, dışlanma durumunda dorsal anterior cingulate kortekste (dACC) aktivite artışı olduğu gözlenmiştir. Fiziksel acının düzenlenmesiyle ilgili olan bu beyin bölgesinin aynı zamanda sosyal dışlanmanın yarattığ stresten de etkilendiği anlaşılmaktadır. Bu çalışma, sosyal dışlanma ve fiziksel acının ortak bir nörobilişsel temele sahip olduğunu göstermesi bakımından önemlidir.

Fiziksel acı ve sosyal dışlanma arasındaki bu ilişkinin kaynağını açıklamaya yönelik ortaya atılan teorilerden biri Sosyal Acı Teorisi'dir (Social Pain Theory). MacDonald ve Leary'nin 
(2005) geliştirdiği bu teoriye göre insanlar ilişkilerden veya gruplardan dişlandıklarında bir tür sosyal acı yaşamaktadırlar. Nasıl ki fiziksel acı organizmanın hayatta kalmasını tehdit eden durumlarda bir alarm olarak devreye giriyorsa, sosyal acı da buna benzer şekilde, sosyal bir tür olan insanın gruptaki varlığını tehdit eden durumlarda devreye girmekte ve fiziksel acıya karşı verilen tepkilere benzer tepkiler doğurmaktadır. Organizmanın yaşamsal tehditlerden kaçınabilmesi için çalışan adaptif bir fizyolojik mekanizma olan fiziksel acı sistemi, grubun dışında kalmanın yarattı̆ uzak geçmişi göz önüne alındığında grup dışında kalmak yaşamsal bir tehdit oluşturmuştur. Dolayısıyla fiziksel acı ve sosyal dışlanmanın beden üzerindeki etkileri, her ikisinde de doğan tepkinin hızlı devreye girmesi, savunmacı davranışlar yaratmaları, duygusal açıdan oldukça rahatsız edici olmaları, aynı beyin bölgelerini aktive etmeleri gibi açılardan ortaktır. Sosyal Acı Teorisi deneysel bulgularla da desteklenmiştir (örn., MacDonald, Kingsbury ve Shaw, 2005; Sleegers, Proulx ve van Beest, 2017; Riva, Wirth ve Williams, 2011).

Dışlanma, beyin aktivitelerinde yarattığı değişimin yanında diğer bazı fizyolojik fonksiyonları da etkilemektedir. Bununla ilgili bir çalışmada katılımcılar sanal top oyunu oynarken deri 1sıları ölçülmüş ve dışlanma koşulundakilerin parmak sıcaklıklarının oyun esnasında düştüğü gözlenmiştir (Ijzerman ve diğer., 2012). Diğer bir araştırmada Moor, Crone ve van der Molen (2010), beklenmeyen sosyal reddedilmenin kalp atım hızında düşüşe yol açtığını tespit etmişlerdir. Dışlanmanın hormonlar üzerindeki etkisini inceleyen Seidel ve arkadaşları (2013) ise katılımcıların testosteron seviyelerinde sosyal dışlanma sonrasında bir düşüş gerçekleştiğini bulmuşlardır.

Sosyal dışlanmanın algısal mekanizmalar üzerindeki etkileri de pek çok araştırmacının merak konusu olmuştur. Zhong ve Leonardelli (2008) dışlanma ve sıcaklık algısı arasındaki ilişkiyi inceledikleri çalışmalarında, deneysel manipülasyonun ardından katılımcılardan oda sıcaklığını tahmin etmelerini istemiş, sosyal dışlanma deneyimi yaşatılan katılımcıların odayı diğerlerinden daha soğuk algıladıkları bulgusuna ulaşmıştır. Aynı çalışmanın ikinci deneyinde katılımcılar bir pazarlama anketini cevaplamışlar, dışlanan katılımcıların sıcak yiyecek ve içecekleri dışlanmayanlara göre daha arzulanır buldukları görülmüştür.

Dikkat ve dışlanma arasındaki ilişkiyi bir dizi deneyle araştırdıkları çalışmalarında DeWall, Maner ve Rouby (2009), sosyal dışlanma deneyiminin ardından katılımcıların farklı duygular yansıtan bir grup yüz fotoğrafı arasındaki gülümseyen yüzlere yönelik dikkatlerini çeşitli şekillerde ölçmüştür. Bulgulara göre dışlanan kişiler gülümseyen yüzleri dişlanmayanlara göre daha hızlı tespit etmekte, dikkatlerini gülümseyen yüzler üzerinde daha uzun süre tutmakta ve bunlardan daha zor ayırmaktadırlar. Başka bir çalışmada sosyal dışlanmanın, dâhil olma ve dışlanmayla ilgili uyaranları daha kategorik algılamaya yol açtı̆ı gözlenmiştir (Sacco, Wirth, Hugenberg, Chen ve Williams, 2011).

Sosyal dışlanmayla arasındaki ilişkinin masaya yatırıldığı bir başka psikolojik yapı bellektir. Gardner, Pickett ve Brewer (2000) katılımcılara, kabul ve reddedilme deneyimi yaşamalarının ardından sosyal ve bireysel olaylar içeren bir günlük okutmuş, sonrasında sürpriz bir şekilde bu olayları hatırlamalarını istemiştir. Sonuçlar incelendiğinde, reddedilme koşulundakilerin günlükteki sosyal olaylara dair seçici bir bellek performansı sergiledikleri görülmüştür. Öte 
yandan dışlanmanın belleği olumsuz yönde etkilediğini ortaya çıkaran başka araştırmalar da yapılmıştır (örn., Hess ve Pickett, 2010).

Dışlanma yaşantısı bireylerin öz-düzenleme (self-regulation) becerileri üzerinde de bozucu bir etki yaratmaktadır. Baumeister ve arkadaşları (2005) dışlanmaya maruz bıraktıkları katılımcılardan, tadı kötü fakat sağlığa faydası olan içecekleri içmelerini istemişler, dışlanan katılımcıların bunları içmekte diğerlerinden daha isteksiz oldukları bulgusuna ulaşmışlardır. Benzer şekilde yine dışlanan katılımcılar sağlıksız atıştırmalıkları daha fazla yeme eğilimi göstermişlerdir. Bunlar, davranışları sosyal olarak belirlenmiş standartlara uydurabilme kapasitesine işaret eden öz-düzenleme becerisini temsil etmekte ve dışlanmanın bu beceriyi zayıflattığı anlaşılmaktadır.

Sosyal dışlanmanın insanların bilişsel becerilerini nasıl etkilediğine dair yukarıda bahsettiklerimizin dışında pek çok araştırma mevcuttur. Gruplardan ve ilişkilerden dışlanmak bilişsel performansımıza zarar vermekte, mantık yürütme ve düşünme becerilerimizi zayıflatmaktadır (Baumeister, Twenge ve Nuss, 2002). Bunun yanısıra dişlanmanın bireyin duygulanımını ne yönde etkilediği sorusu araştırmacıların çokça üzerindeki durdukları bir başka noktadır. Grup dışında kalmanın, reddedilmenin insanlar için rahatsız edici ve istenmeyen bir durum olduğunu düşündüğümüzde, sosyal dışlanmanın olumsuz duygular ortaya çıkaracağını öngörmek akla yatkın görünmektedir; lakin ilgili literatürde dışlanmanın duygulanımı etkileyip etkilemediğine dair bir mutabakat yoktur (Gerber ve Wheeler, 2009). Kimi çalışmalar dışlanmaya bağlı duygulanım değişimleri tespit etmişken (örn., Pickett, Gardner ve Knowles, 2004), kimileri herhangi bir etkiye rastlamamıştır (örn., DeWall ve Baumeister, 2006).

İlk çalışmalar, dışlanma deneyiminin insanların kendilerini kötü hissetmeleri sonucunu doğurduğunu göstermiştir. Sosyal dışlanma katılımcıların üzüntü, öfke gibi duygularında artışa sebep olmaktadır (Hawkley, Williams ve Cacioppo, 2011; Smith ve Williams, 2004; Williams, Cheung ve Choi, 2000). Hatta sanal top oyunu paradigması kullanilan bir araştırmada, diğer oyuncuların bilgisayar tarafından yönetildiği söylenen katılımcılar bile oyundan dışlanmaktan rahatsızlık duymuşlardır (Zadro, Williams ve Richardson, 2004). Benzer bir çalışmada, katılımcılara diğer oyuncuların hoşlanılmayan bir dış grubun (Ku Klux Klan) üyeleri oldukları belirtilse dahi dışlanma durumu yine olumsuz duygulanıma yol açmıştır (Gonsalkorale ve Williams, 2007). Van Beest, Williams ve Van Dijk (2011) yürüttükleri bir deneyde, sanal top oyununda top yerine temsili bir bomba koymuşlar ve katılımclara bombanın oyun süresince herhangi bir anda patlayabileceği, patlama anında bombayı hangi oyuncu tutuyorsa onun öleceğini söylemişlerdir. Bu tip bir oyundan dışlanmak bile katılımcıların duygulanımını olumsuz etkilemiştir.

Diğer bazı araştırmalarda ise yukarıdaki bulguların aksine sosyal dışlanmanın duygulanımı olumlu veya olumsuz yönde etkilemediği sonucuna ulaşılmıştır (Aydin ve diğer., 2011; DeWall ve Baumeister, 2006). Bu durum kimi yazarlarca "duygusal donukluk" hipoteziyle (numbness hypothesis) açıklanmaktadır. Şöyle ki, dışlanmanın yarattığı sosyal acının ardından duygu sistemi kısa bir süreliğine devreden çıkmakta ve bunun sonucunda hissizlik oluşmaktadır (Baumeister, Brewer, Tice ve Twenge, 2007). Organizma bu sayede, gerekli tedbirleri (kaçma, vb.) alabilmek adına göstereceği çaba için ihtiyaç duyduğu zamana sahip 
olmaktadır. Duygulanımdaki değişimler ise bu sürecin ardından kendini gösterecektir. $\mathrm{Bu}$ yaklaşım temelini, daha evvel sözünü ettiğimiz ve sosyal acı ile fiziksel acının ortak nöroanatomik temellere sahip olduğunu iddia eden (Eisenberger, Liberman ve Williams, 2003) görüşten almaktadır. Buna göre, sosyal dişlanma karşısında verilen tepkiler de fiziksel acıya karşı verilen tepkilere (analjezi, hissizlik, vb.) benzeyecektir. Nitekim DeWall ve Baumeister'ın (2006) araştırması, dışlanma deneyimi yaşamanın fiziksel acıya karşı toleransı arttırdığını ve acı duyarlılığını zayıflattığını ortaya koymuştur. Öte yandan Bernstein ve Claypool (2011) bu durumun dışlanma deneyiminin şiddetine bağlı olarak değişebileceğini iddia etmişlerdir. Katılımcıları ılımlı olarak algılanan şiddette dışlanmaya maruz bıraktıklarında fiziksel acıya duyarlılıklarının arttığı, diğer yandan şiddetli olarak algılanan dışlanmaya maruz bıraktıklarında ise bu duyarlılığın azaldığı yönünde bulgulara ulaşmışlardır.

Gerber ve Wheeler (2009), sosyal dişlanmanın duygulanım üzerindeki etkilerine dair literatürdeki bu çelişen bulguları inceledikleri bir meta-analiz çalışmasında, dışlanmanın duygulanımı olumsuz etkilediği görüşünü destekleyen bir sonuca varmışlardır. Bulgular arasındaki bu belirgin çelişkinin kaynağı, dışlanma için kullanılan deneysel paradigmaların farklı etkiler doğurması ve duygulanımı ölçmek için kullanılan araçların farklılığı olabilir. Anlaşılan o ki, konunun bu boyutunun tam olarak aydınlığa kavuşturulması için daha fazla çalışmaya ihtiyaç vardır.

Dışlanmaya karşı verilen otomatik tepkilerin birtakım bireysel faktörlerden etkilendiği sonucuna varan bazı çalışmalara da değinmek gerekirse, bunlardan birinde Weik, Maroof, Zöller ve Deinzer (2010), sanal top oyunundan dışlanmanın psikolojik olarak kadınları erkeklerden daha çok etkilediğini gözlemlemişlerdir. Sosyal dişlanma ile yaş arasındaki ilişkiyi ele alan bir başka çalışmada, dişlanma deneyimi yaşamak 60 yaş altı bireylerde olumlu duygulanıma zarar vermişken, 60 yaş üstü bireylerde bu durum görülmemiştir (Hawkley, Williams ve Cacioppo, 2011). Mendes, Major, McCoy ve Blasovich (2008) dışlama kaynağının dışlananla aynı yahut farklı ırktan olmasının farklı bir etki yaratıp yaratmadığını incelemişler ve farklı ırktan biri tarafından dışlanmanın daha fazla öfke yarattığını bulmuşlardır. Buckner, DeWall, Schmidt ve Maner (2010), sosyal kaygı düzeyi yüksek olan kişilerin dışlanma tehdidiyle karşılaştıklarında sosyal kabul işaretlerine daha çok dikkat harcadıklarını gözlemlemişlerdir. Bununla birlikte McDonald ve Donnellan (2012), kişilik özelliklerinin sosyal dışlanma karşısında verilen tepkilerle büyük oranda ilişkili olmadığını savunmaktadır.

\section{Kısa Vadede Ortaya Çıkan Tepkiler}

Sosyal dişlanmanın yol açtığı sosyal acı ve üzüntü, öfke gibi duygular bireyleri alarma geçirmekte ve dikkatlerini dışlanma sürecine odaklamaktadır. Bu aşamanın ardından dışlanmış kişi birtakım sorularla karşı karşıya kalır: Diğerleri tarafından dışlanmasının sebebi nedir? Bu durumla nasıl baş edecektir? Gruba tekrar kabul edilmek için neler yapmalıdır? Bu ve buna benzer sorular dışlanmış kişinin ilerleyen aşamalarda nasıl davranışlar sergileyeceğine dair ipuçları verir. Araştırmacılar, dışlanmayı takip eden kısa bir süre içerisinde insanların genellikle olumlu sosyal (prosocial) veya olumsuz sosyal (antisocial) davranışlar benimsediklerini saptamışlardır. 
Dışlanmanın saldırganca davranışlar meydana getirip getirmediğini bir dizi deneyle inceleyen ilk çalışmalardan birinde Twenge, Baumeister, Tice ve Stucke (2001), dışlanan katılımcıların kendilerinin eleştirilmesi karşısında daha agresif bir tutum sergilediklerini ortaya koymuşlardır. Aynı çalışmanın diğer bir deneyinde katılımcılara, bir bilgisayar oyununda karşılarındaki kişiyi rahatsız edici bir sese maruz bırakma şansı verilmiş, dışlanan katılımcıların hem ses düzeyini daha çok arttırdıkları, hem de diğerinin sese maruz kalma süresini daha uzun tuttukları gözlenmiştir. Dahası, dışlanan katılımcılar kendilerini herhangi bir şekilde kışkırtmayan, ilk defa karşılaştıkları kişilere karşı da saldırganca davranmışlardır.

Saldırgan davranışın farklı şekilde ölçüldüğü başka bir çalışmada katılımcılara, beraber sanal top oyunu oynadıkları diğer oyunculara acı sos tattırtma imkânı verilmiş, oyundan dışlanan katılımcıların diğerlerine daha fazla miktarda acı sos verme eğiliminde oldukları bulunmuştur (Van Beest, Williams ve Van Dijk, 2011). Moor ve arkadaşları (2012) ise katılımcılara dışlanma deneyiminin ardından diktatör oyunu (dictator game) oynatmış ve dışlanan katılımcıların kendilerini dışlayanlara karşı cezalandırıcı bir tavır benimsediklerini gözlemlemişlerdir.

DeWall, Twenge, Gitter ve Baumeister (2009) sosyal dışlanmanın insanlarda düşmanca bir bilişsel eğilim (hostile cognition bias) ortaya çıkardığını tespit etmişlerdir. Yürüttükleri deneylerden birinde katılımcılardan saldırganca anlam taşıyan (kan, bıçak, vb.) ve çok anlamlı (gece, kırmızı, vb.) bir grup kelimenin birbirleriyle benzerliklerini değerlendirmeleri istenmiş, dışlanan katılımcıların bunları daha benzer algıladıkları görülmüştür. Diğer bir deneyde ise dışlanan katılımcılar, birkaç harfi eksiltilen kelimeleri saldırganca kelimelerle tamamlamaya daha fazla eğilim göstermişlerdir. Son olarak yine dışlanan katılımcılar başka bir kişinin muğlâk sayılabilecek eylemlerini değerlendirdiklerinde bunları diğerlerinin değerlendirmelerine göre daha düşmanca bulmuşlardır. Tüm bu bulgular sosyal dışlanmanın yol açtığı saldırganlığın altında yatan bilişsel süreçlerin bir kısmını açıklaması bakımından önem taşımaktadır.

Sadece başkalarına yönelik saldırganlıkta değil, kişinin kendine yönelik saldırganlığında da (self-defeating behavior) dışlanma yaşantısının etkisi vardır. Twenge, Catanese ve Baumeister (2002) katılımcılara, deneysel amaçla hazırlanmış bir loto oynattıklarında dışlanma koşulundakilerin daha riskli tercihler yaptıklarını görmüşlerdir. Ayrıca dışlanan katılımcılar sağlığa iyi gelen davranışlara daha az yönelmekte ve önemli işleri yapmayı daha fazla ertelemektedirler.

Dışlanmanın saldırganca tutumlar ve davranışlar üzerindeki etkilerini araştıran çeşitli çalışmaları inceleyen Leary, Twenge, ve Quinlivan (2006), literatürdeki bulguların çoğunun dışlanmanın saldırganlığa yol açtığı görüşünü desteklediğini öne sürmüşlerse de bu iddianın aksini doğrulayan araştırmalara rastlamak mümkündür. Dışlanan bireylerin gruplar veya yeni insanlar tarafından tekrar kabul edilebilmek amacıyla isteklere daha fazla boyun eğmek, daha taklitçi ve işbirlikçi olmak gibi olumlu sosyal davranışlara yöneldiği, konuya diğer tarafından bakan araştırmacıların savunduğu görüştür (Williams ve Nida, 2011). Yine vurgulamak gerekirse, gruplara ait olmak yaşamsal bir ihtiyaçtır ve dışlanma durumunda ait olma ihtiyacımızı yeniden karşılamak amacıyla diğer insanların sosyal kabulünü sağlayacak davranışlar benimsememiz beklenebilir (Baumeister ve Leary, 1995). Maner ve arkadaşları (2007), yeniden bağ kurma hipotezi (social reconnection hypothesis) adındaki bu görüşü 
doğrulamak amacıyla yürüttükleri deneylerde, dışlanan katılımcıların yeni arkadaşlıklar kurmakta daha hevesli olduklarını, diğerleriyle çalışma isteklerinin daha fazla olduğunu ve yeni etkileşim partnerlerini daha fazla ödüllendirdiklerini bulmuşlardır.

Williams, Cheung ve Choi (2000) sosyal dışlanma ile sosyal uyma arasındaki ilişkiyi inceledikleri çalışmalarında, dışlanan katılımcıların grubun yanlış kanılarına daha fazla uyma gösterdiklerini ortaya koymuşlardır. Over ve Carpenter (2009) ise ortalama yaşları 5 olan bir grup çocuğa hareket eden geometrik şekillerin bulunduğu videolar izleterek dişlanma manipülasyonu yaratmış, diğer şekillerin birinden sürekli uzaklaştığı videoları izleyen (dışlanma koşulundaki) çocukların, müteakip bir görevde yetişkin deneyciyi daha fazla taklit ettikleri sonucuna ulaşmışlardır. Sosyal dışlanmanın ardından davranışsal taklit eğilimindeki artış yetişkin katılımcılarda da gözlenmiştir (Lakin ve Chartrand, 2005).

Dışlanma tehdidinin olumlu sosyal davranışları ne yönde etkilediğini inceleyen bazı çalışmalarda ise dışlanmanın bu tip davranışları azalttığı yönündeki neticelere rastlanmıştır. 16 ve 17 yaşındaki ergenlerle gerçekleştirilen bir çalışmada dışlanma tecrübesi yaşamanın olumlu sosyal davranışları azalttığı, söz konusu azalmanın bir kişilik testiyle ölçülen "açıklık" (openness) özelliğine daha fazla sahip olanlarda daha belirgin olduğu anlaşılmıştır (Coyne, Gundersen, Nelson ve Stockdale, 2011). Balliet ve Ferris (2013) ise katılımcılara, ortak bir amaç uğruna çalışan bir takımın üyesi olduklarına dair bir senaryo okutarak dışlanma manipülasyonu yaratmış ve ardından katılımcıların takımın diğer üyelerine yardım etme niyetlerini ölçmüştür. Beklendiği gibi dışlanan katılımcıların yardım etme niyetleri daha düşük bulunmuştur. Bir başka çalışmada dışlanan katılımcıların bir öğrenci fonuna daha az para bağışladıkları, gelecekteki laboratuar deneylerine katılmakta daha gönülsüz oldukları, laboratuar ortaminda yaratılan ufak bir kazada (kalemlerin yere düşmesi) daha az yardımsever davrandıkları ve başka bir öğrenciyle oynadıkları oyunda daha az işbirliği yaptıkları gözlenmiştir (Twenge, Baumeister, DeWall, Ciarocco ve Bartels, 2007).

Sosyal dişlanmanın duygulanım üzerindeki etkileri konusundaki ihtilafa benzer şekilde, dışlanma ile olumlu sosyal ve olumsuz sosyal davranışlar arasındaki ilişkinin dinamikleri hakkında da bir görüş birliği henüz karşımıza çıkmamaktadır. Bununla birlikte sayısız araştırmaya dayanarak kesin bir dille söyleyebileceğimiz bir şey var ki, gruplardan dişlanmak insanın sosyal davranışlarını fark edilir düzeyde etkilemektedir.

\section{Uzun Süreli Dışlanmanın Ortaya Çıkardı̆̆ı Tepkiler}

Laboratuar ortamlarında yaşatılan birkaç dakikalık sosyal dışlanma deneyiminin bile bireylerin davranışlarında, duygularında ve bilişsel süreçlerinde ne denli etkili olduğunu önceki sayfalarda gördük. Oldukça kısa süren bir dışlanma yaşantısı dikkat, bellek gibi bilişsel becerilerden tutun da saldırganlık, uyma gibi sosyal davranışlara kadar pek çok psikolojik ve fizyolojik mekanizmayı etkileyebilecek bir güce sahiptir. Peki, daha uzun süren, hatta aylar, yıllar boyu süren bir dışlanma deneyimi insanlar üzerinde nasıl bir sonuç doğuracaktır? Dışlanma olgusunu daha önce değindiğimiz boyutlarıyla ele alıp, ortaya sağlam bulgular koyabilen araştırmacılar bu soruyu kolay yantlayamıyorlar; zira sosyal dışlanmanın uzun vadede yarattığı etkileri incelemek beraberinde ciddi yöntemsel sinırlılıklar da getirmektedir. Dolayısıyla ilgili literatürde bu noktaya değinen veriler görece kısıtlıdır. 
Uzun süreli dışlanmanın bireyler üzerindeki etkilerinin, evde, işte veya toplumda önem verilen kişiler ya da gruplar tarafından devamlı olarak yahut tekrar tekrar yok sayılmak, dışlanmak sonucunda gözlenebileceği düşünülmektedir (Williams, 2007). Geniş bir zaman dilimini kapsayan ve tekrar eden dişlanma deneyimlerine dair gözlemler, genellikle bu tür dışlanmalara maruz kalan kişilerle yapılan doğrudan görüşmeler ve bu kişilerin günlüklerinin ve anılarının incelenmesi sayesinde elde edilmektedir. Süreç içerisinde bu kişiler dışlanmayla başa çıkma kaynaklarının tükendiğini düşünmekte, yabancılaşma ve değersizlik hislerine kapılmaktadırlar. Ayrıca intihar düşünceleri ve teşebbüsleri, depresyon gibi psikolojik sıkıntıların bu insanlarda daha yaygın olduğu görülmektedir (Williams ve Nida, 2011; Williams, 2001).

Tekrar eden ve süreklilik taşıyan türde bir dışlanma yaşamanın insanlarda kendi kendini izole etme, sosyal çekilme, yalnızlık gibi neticelere yol açtığı pek çok vakada rastlanmasına karşın bazı analizlerde bunun şiddet eylemlerini tetiklediği iddia edilmiştir. Leary, Kowalski, Smith ve Philips (2003), 1995 ile 2001 yılları arasında ABD'de gerçekleşen okul katliamı vakalarını medya taraması yoluyla incelemişler, katliam faillerinin çoğunluğunun süregelen bir alay, zorbalık ve dışlanmaya maruz kaldıklarını, bir kısmının ise karşı cins tarafından reddedildiğini tespit etmişlerdir. Okul katliamları ve sosyal dışlanma arasındaki ilişkiyi mercek altına alan başka analizler de yapılmış (örn., Wike ve Fraser, 2009), bu olayları engellemek adına okul ortamındaki akran ilişkilerinin geliştirilmesi gerektiği vurgulanmıştır.

Dışlanma yaşantısı sonucu gözlenen otomatik ve erken aşamadaki tepkileri deneysel yöntemlerle incelemek mümkün olsa da, uzun vadede ortaya çıkan tepkileri laboratuar ortamında açığa çıkarmak gerek bilimsel etik sorunlar, gerekse metodolojik zorluklar nedeniyle mümkün değildir. Bu sebeple araştırmacılar, konunun bu yönünün yarattığ literatür boşluğunu dolaylı ölçümler ve analizler sayesinde doldurmaya çalışmaktadırlar.

\section{Sosyal Dışlanma Olgusunu Açıklayan Teorik Yaklaşımlar}

İnsan gruplarında, hayatta kalma ve üremeyle ilgili problemlerin birçoğunun üstesinden gelmek tek başına mümkün değilken, bu problemler yardımlaşma, işbirliği ve koordinasyon gibi sosyal davranışlarla çok daha kolay aşılabilmektedir. Öte yandan, geniş ölçekte grubun çıkarlarına hizmet eden sosyal sözleşmeler bazen tek tek grup üyelerinin kişisel menfaatlerine ters düşebilmektedir. Eğer çok fazla üye bencil hedeflerine ulaşmak için çabalarsa diğer üyeler sosyalliğin bedellerini ödemeye yanaşmayacak, böylece grup bağlılı̆̆ı, dolayısıyla da sosyallik tehlikeye girecektir (Dunbar, 2007). İşte bu noktada dışlanma tehdidi devreye girmekte, grup bağlılığının ve bütünlüğünün korunmasında önemli bir rol üstlenmektedir. İnsanlar sömürücü, öngörülemez, fazlaca bağımsız ve bir dış-grup üyeliğine işaret eden davranışlar sergileyen grup üyelerine karşı olumsuz hisler beslemeye olanak sağlayan algısal ve bilişsel adaptasyonlara sahiptir (Kerr ve Levine, 2008). Bu adaptasyonlar sayesindedir ki grubun istikrarına ve birliğine zarar verecek sosyal ihlallere yönelen bireyler tespit edilmekte, onları bu istenmeyen davranışlarından vazgeçirecek tedbirlere (sosyal etkileşimlerden mahrum bırakmak, vb.) başvurulmaktadır. Wesselmann ve arkadaşları (2013) yaptıkları bir çalışmada bu görüşü deneysel olarak test etmişler ve diğerleri tarafından gruba yük olarak algılanan katılımcıların daha fazla dışlandıklarını bulmuşlardır. 
Gruplar halinde yaşayan canlı türlerinin bireyleri için grupta kalmanın önemi hayvan deneylerinde de gözlenmiştir. Örneğin, tarla fareleri (prairie vole) üzerinde yürütülen bir çalışmada kronik stresi deneysel olarak değişimlemek amacıyla uzun süreli sosyal izolasyon yaratılmış, dört hafta boyunca diğerlerinden izole edilen farelerin, normal sosyal etkileşimlere giren farelere kıyasla daha olumsuz fizyolojik ve psikolojik tepkiler geliştirdiği bulunmuştur (Grippo, 2009). Bu bulgu, tarla fareleri ile insanların sahip olduğu bazı sosyal ve fizyolojik mekanizmaların (örn. tek eşlilik, her iki ebeveynin de yavru bakımında rol üstlenmesi, kalp fonksiyonlarını düzenleyen sistemlerin benzerliği) iki tür için ortak olması nedeniyle kayda değerdir. Evrimsel açıdan bakıldığında, sosyal sistemler geliştirmek yönünde evrilen canlıların dışlanma durumunda karşılaştıkları risklerin ve bu tehdit karşısında verdikleri tepkilerin benzer olduğunu söylemek mümkündür. Grubun dışında kalmak bir nevi ölüm anlamına geldiğinden, dışlanma işaretlerini zamanında tespit edebilen ve bunlara uygun tepkiler verebilen organizmalar hayatta kalma ve üremede daha başarılı olmuş, dolayısıyla bunu sağlayan genleri popülasyonda daha çok yayabilmiştir (Wesselmann, Nairne ve Williams, 2012).

Tıpkı insanlar gibi küçük gruplar halinde yaşayan şempanzelerde de sosyal dışlamanın bazı biçimlerine rastlanmaktadır. Gombe' de yaşayan şempanzeler üzerinde 23 yıl boyunca yapılan gözlemlerde, sosyal dışlama ya da reddetme olarak ele alınabilecek vakaların yaşandığı üç farklı davranışsal bağlam tespit edilmiştir. Bölgedeki şempanzeler, kendi gruplarının diğer üyeleriyle rekabete dayalı etkileşimlere girdiklerinde, diğer şempanze topluluklarının üyeleriyle etkileşime girdiklerinde ve bir grup üyesi anormal, olağandışı olarak algılanan davranışlar sergilediğinde sosyal dışlama anlamına gelen tepkiler verebilmektedir (Goodall, 1986). Söz konusu tepkiler, insan topluluklarında evrildiği şekilde karmaşık grup cezalandırmaları olarak yorumlanamasa da, evrim tarihinde sosyal dışlanmanın oldukça uzun zamandır grup yaşamının bir parçası olduğunu göstermektedir. Bu savı destekleyen bir başka inceleme de McGuire ve Raleigh (1986) tarafından ortaya konmuştur. İnsan dişındaki primatların dişlanma karşısında verdikleri fizyolojik tepkileri inceleyen araştırmacılar, baskın bir primat erkeğinin diğer erkekleri görmesi engellenecek şekilde izole edilmesi halinde kanındaki genel serotonin düzeyinin düştüğünü ve itaatkâr davranışlarında artış gözlendiğini rapor etmişlerdir.

Gerek primatlar, gerek primatlar dışındaki bazı memeli türleri, gerekse de modern hayattan uzak günümüz insan topluluklarından elde edilen bilgiler bir gruba dâhil olmanın, kökenleri oldukça eskiye dayanan adaptif bir ihtiyaç olduğu fikrini doğurmaktadır. Baumeister ve Leary (1995) konuyu geniş çaplı bir şekilde ele aldıkları öncü makalelerinde ait olma ihtiyacından, tüm kültürlerde ve insanlarda evrensel olarak var olan doğal bir ihtiyaç olarak bahsetmektedirler. Bununla birlikte bu ihtiyacın güçlülüğü, ifadesi, tatmini gibi unsurlar kültürler ve bireyler arası değişkenlerden etkilenebilmektedir. İnsanlar sürekli ve kalıcı kişilerarası ilişkiler kurduklarında olumlu, sosyal etkileşimler ve ilişkilerden mahrum kaldıklarında ise olumsuz hisler yaratan bir duygu mekanizmasına sahiptirler. Bu mekanizmanın gelişimi ise atalarımızın tekrarlayan bir şekilde karşılaştığı belirli adaptif problemleri çözme sürecinde gerçekleşmiştir. Doğal seçilim insan zihnini eş bulma, işbirliği yapma, kaynak bulma, yırtıcılardan korunma, avlanma, yön bulma, çocuk bakımı sağlama gibi sürekli karşı karşıya gelinen adaptif problemleri çözmek üzere tasarlamıştır (Tooby ve 
Cosmides, 2005). Bu ve buna benzer problemlerin üstesinden gelmek grup içi koalisyonlar ve kalıcı ilişkiler kurmak yoluyla çok daha kolay olmuştur; dolayısıyla sosyal etkileşimlere dâhil olmakla karşılanan aidiyet ihtiyacı doğuştan gelen temel bir ihtiyaçtır.

Bir kısmını önceki sayfalarda gördügüumüz araştırma bulgularından hareketle sosyal dişlanmaya dair pek çok hipotez ortaya atılsa da, bu olguyu kapsamlı ve çok boyutlu şekilde ele alan başlıca üç yaklaşım bulunmaktadır: (1) Sosyal izleme sistemi ve sosyometre teorisi, (2) bilişsel yıkım ve öz-düzenlemenin bozulması modeli ve (3) Williams'ın psikolojik dışlama modeli.

\section{Sosyal İzleme Sistemi ve Sosyometre Teorisi}

Pickett ve Gardner (2005) geliştirdikleri modelde, "sosyal izleme sistemi" (social monitoring system) adını verdikleri ve diğer fizyolojik ve psikolojik mekanizmalar gibi evrensel olarak tüm insanların sahip olduğunu varsaydıkları adaptif bir sistemden söz etmektedirler. Bu sistem, açlık ve susuzluk gibi durumlarda organizmayı yiyecek, su ihtiyacını gidermeye güdüleyen ve böylece vücudun yaşamsal fonksiyonlarının devamını sağlayan homeostatik sistemlere benzemektedir. Nasıl ki besin ihtiyacı ortaya çıktığında organizma bunun sinyalini vermekte ve optimum düzeyde tatmin edilmesini sağlamaktadır, sosyal izleme sistemi de ait olma ihtiyacı tehdit altına girdiğinde sinyal vermekte, bunun giderilmesine yönelik bilişsel ve davranışsal mekanizmaları devreye sokmaktadır.

Yazarlara göre (Pickett ve Gardner, 2005) bütün düzenleyici sistemlerde olduğu gibi sosyal izleme sisteminde de mevcut ihtiyaçları tespit eden, bu ihtiyaçları karşılayacak sinyalleri saptayan ve yaşamsal çevreyi izleyerek davranışı yönlendiren hedef yönelimli evrilmiş bir mekanizma işlemektedir. Bireyler, çevrelerindeki ait olma ve kabule işaret eden olumlu sosyal enformasyonlara da, reddedilme ve dişlanmaya işaret eden olumsuz sosyal enformasyonlara da duyarlıdırlar. Dolayısıyla sosyal izleme sistemi beklendiği gibi işleyen bir kişinin, dışlanma yaşantısının ardından kişilerarası duyarlılığı artacak, sosyal çevresindeki kabul işaretlerine yönelik dikkati keskinleşecektir. Nitekim bazı deneylerde dışlanan katılımcıların gülümseyen yüzlere yönelik dikkatlerinin arttı̆̆1 (DeWall, Maner ve Rouby, 2009) ve samimi olan ile samimi olmayan gülümsemeleri daha iyi ayırt ettikleri (Bernstein, Sacco, Brown, Young ve Claypool, 2010) bulunmuştur. Sosyal çevreye ilişkin bu artan duyarlılık, kişinin ait olma ihtiyacını tekrar optimum tatmin düzeyine ulaştırmasını sağlayacak davranışlara öncülük etmektedir. Dışlanma sonrası sosyal izlemedeki hassasiyeti artmayan bireyler muhtemelen günlük hayatta daha fazla dışlanmaya maruz kalmaktadırlar (Pickett ve Gardner, 2005).

Sosyometre teorisi de (sociometer theory; Leary ve Baumeister, 2000; Leary ve diğer., 1995) dişlanma olgusunu sosyal izleme modeliyle paralel bir yaklaşımla ele almaktadır. Bu teoriye göre insan evriminin şekillendiği atasal çevre içinde grubun dışında kalmak büyük tehditler içerdiğinden, atalarımız diğerlerinin kendilerine verdiği değer ve kabul düzeyini izleyen bir mekanizma geliştirmişlerdir. Sosyometre adı verilen bu psikolojik mekanizma, diğerlerinin bireyi ne ölçüde kabul ettiği ve ne ölçüde reddettiğiyle ilgili sosyal çevre işaretlerini sürekli olarak gözlemektedir. Eğer kişi sosyal ilişkiler içerisinde kendini değersiz, önemsiz ve uzak hissederse, sosyometre o kişinin dikkatini sosyal kabulle ilgili potansiyel tehditlerin üzerine çekmekte ve önleyici davranışları teşvik etmektedir. Sosyometrenin ait olma ihtiyacının karşılanma düzeyine dair ürettiği duygusal çıktı, "benlik saygısı" ya da "benlik değeri" olarak 
bilinmektedir (Leary, 1999). Yüksek benlik saygısı, tatmin edici ve değerli sosyal ilişkiler kurulduğu anlamına gelirken, düşük benlik saygısı ilişkilerden dışlanma ve değersiz görülme anlamına gelmektedir. Dolayısıyla aslında bireylerde benlik saygısını sürekli yüksek tutmaya yönelik bir mekanizma değil, sosyal dişlanmadan kaçınmaya yönelik bir mekanizma bulunmaktadır (Leary ve diğer., 1995). Bunun ne derece başarıldığının ölçüsünü ise bize benlik saygısı düzeyi vermektedir.

\section{Bilişsel Yıkım ve Öz-düzenlemenin Bozulması Modeli}

Bilişsel yıkım ve öz-düzenlemenin bozulması modeli (cognitive deconstruction and self-regulation impairment) sosyal dışlanmanın ardından meydana gelen birtakım bilişsel işlev bozulmalarına dair bulgulara dayanmaktadır. Modelin savunucularına göre (Baumeister ve diğer., 2005; Baumeister ve DeWall, 2005) bilişsel bilgi işleme ve öz-düzenleme, duygu gibi temel içsel süreçlerdendir. İnsandaki bilgi işlemenin özelliklerinden biri adaptif problemlerin üstesinden gelmek üzere seçilmiş düşünme ve mantık yürütme becerisidir. Benzer şekilde, davranışları sosyal standartlara göre düzenleyebilmeyi, grup üyeliğini sürdürme ve güvenlik karşılığında bencil eğilimlerden kaçınmayı mümkün kılan öz-düzenleme de insanlarda son derece güçlü ve kritik öneme sahip bir özelliktir. Öz-düzenleme becerisi sayesinde insanlar düşüncelerini, duygularını ve davranışlarını ait oldukları gruplar tarafından belirlenmiş normlara göre değiştirebilmektedirler. İşte insandaki bu iki temel özellik sosyal dışlanma yaşantısını takiben olumsuz yönde değişen en önemli içsel süreçlerdir (Baumeister ve DeWall, 2005).

Dışlanmanın ardından bilişsel becerilerin ve öz-düzenlemenin bozulacağı iddiası deneysel verilerle de desteklenmiştir. Önceki bölümde bazılarının sözünü ettiğimiz bu araştırmalarda (örn., Baumeister, Twenge ve Nuss, 2002; Baumeister ve diğer., 2005) dişlanmaya maruz bırakılan katılımcıların mantıklı ve dikkatli akıl yürütme becerilerini ölçen testlerden daha düşük puanlar aldıkları, daha çok hata yaptıkları, sağlıksız besinleri tüketme konusunda kendilerini daha zor kontrol ettikleri, vb. bulgulara ulaşılmıştır.

\section{Williams'ın Psikolojik Dışlama Modeli}

Williams'ın geliştirdiği psikolojik dışlama modeli dışlanma olgusunu açıklamayı amaçlayan modeller arasında en kapsamlı ve çok boyutlu olanıdır (Williams, 2001; 2007; 2009; Williams ve Zadro, 2005; Williams ve Zadro, 2001). Modele göre insanlar, dişlanacaklarına ya da görmezden gelineceklerine dair işaretleri önceden saptamalarını sağlayan adaptif bir erken tespit sistemine sahiptirler. Bireyler dışlanmayı tespit edebilme ve algılayabilme aşamasında, tıpkı yanık acısını algılamadaki gibi geniş bir yelpazeye yayılmamaktadırlar. Hatta insanlarda dışlanmaya dair bir abartılı tespit yanlılığının (over-detection bias) bulunduğu varsayılmaktadır (Spoor ve Williams, 2007). Şöyle ki, sosyal çevrede gerçek bir dişlanma tehdidi olduğu halde bunu yokmuş gibi algılamanın bedeli, gerçek bir dışlanma tehdidi olmadığı halde bunu varmış gibi algılamanın bedelinden çok daha ağırdır. İkinci durumda sadece yanılmış olursunuz, birinci durumda ise beklemediğiniz ve hazırlıksız olduğunuz halde bir dışlanma yaşayabilirsiniz. Bu görüş Hata Yönetimi Teorisi'nin (Error Management Theory; Haselton ve Buss, 2000) öne sürdüğü ve insan zihninin hayatta kalma ve üreme başarısına hizmet eden bazı hatalı algısal eğilimlere sahip olduğunu savunan iddiasıyla örtüşmektedir. Nihayetinde dışlanma bir kez tespit edildikten sonra buna nasıl tepki verileceği ve bununla nasıl baş 
edileceği ise bireysel faktörlere bağlı olarak değişebilmektedir (Abrams, Weick, Thomas, Colbe ve Franklin, 2011; Bozin ve Yoder, 2008; Hawkley, Williams ve Cacioppo, 2011).

Modele göre dışlanma türleri bazı kriterler temel alınarak sınıflandırılabilir. Bu kriterler görünürlük (visibility), neden (motive), miktar (quantity) ve açılık (clarity) olarak tanımlanmıştır. Görünürlük fiziksel, sosyal ve sanal dişlama olmak üzere üç boyutta ele alınmaktadır. Fiziksel dişlama kovma, uzaklaştırma, sürgün gibi somut ve görünür davranış biçimleri aracılığıyla; sosyal dışlama hedef kişiyle göz göze gelmeme, konuşmama gibi daha belirsiz davranış biçimleri aracılığıyla; sanal dışlama ise telefonlara, mesajlara ve e-postalara yanıt vermeme gibi sanal iletişim araçları üzerindeki davranışlar aracıllğıyla gerçekleşmektedir. Dışlamanın nedenlerine dair sınıflamada ise şu ayrımlar yapılmaktadır: Gerçekte öyle bir durum olmadığ sosyal rollerin gereği (örneğin bir otobüste insanların birbirini dışlaması) sonucu oluşan dışlamalar maksatlı değildir ve belli bir niyet taşımamaktadır. Savunmacı, cezalandırıcı ve ihmal etme biçimindeki dışlamalar ise maksatlıdır ve hedef kişiyi cezalandırma amacı gütmektedir. Son olarak dışlamanın miktarı ve ne ölçüde açık olduğu da modele göre sinıflamaya dâhil edilmesi gereken kriterlerdir.

Williams'ın modeli dışlamanın öncüllerinden de bahsetmekte, insanların diğerlerini dışlama sebeplerini üç başlık altında incelemektedir. Bunlardan birincisi dışlama hedefinin sahip olduğu sosyal açıdan hoşlanılmayan özelliklerdir. İkincisi dışlama kaynağının sahip olduğu ve diğerlerini dışlama eğilimini arttıran kararsız bağlanma gibi özelliklerdir. Üçüncüsü ise sosyal faktörlerin başka türlü bir davranışa izin vermediği durumlardır (örneğin, kalabalık içinde eşine kızan biri onunla herkesin içinde kavga edemeyeceğinden dışlamayı tercih edebilir).

Dışlanma olgusunu açıklarken modelin vurguladığı bir başka nokta, bireylerin dışlanmadan ne kadar etkileneceğini şekillendiren aracı unsurlardır. Dışlanmaya yönelik nedensel atıflar ve bağlanma stilleri, benlik saygısı düzeyi, ait olma ihtiyacı düzeyi gibi bireysel değişkenler, dışlanan kişinin vereceği tepkileri olumlu veya olumsuz yönde etkilemektedir.

Modelin en önemli kısmı belki de dışlanma deneyiminin insanların hangi ihtiyaçlarını tehdit ettiğini açıkladığı kısımdır. Bu kapsamda Williams (2001; 2009) dışlanmadan zarar gören dört temel ihtiyacın sözünü etmektedir: (1) ait olma ihtiyacı, daha önce bahsettiğimiz üzere evrensel olarak tüm insanlarda var olan, gruplara ve ilişkilere kabul edilme ihtiyacı şeklinde tanımlanmakta ve gayet anlaşılır şekilde dışlanma yaşantısından zarar görmektedir. (2) Olumlu benlik saygısına sahip olma ihtiyacı, hedef kişinin diğerleri tarafından kabul görmemenin sebeplerine dair kendini suçlayan atıflarda bulunması sonucu dışlanmadan olumsuz etkilenmektedir. (3) Kontrol ihtiyacı kaynağını, bireylerin sosyal çevrelerini kontrol edilebilir ve öngörülebilir görmek istemelerinden almaktadır. Dışlanma durumunda kişi bu kontrolü yitirdiğini hissetmekte ve sosyal çevreye tekrar kabul edilip edilmeyeceğine dair doğan belirsizlik bir tehdit algısı yaratmaktadır. Son olarak (4) anlamlı varoluş ihtiyacı ise insanların kendi varoluşlarına bir anlam, değer ve önem yükleme eğilimlerinden kaynaklanmakta ve dışlanma sonucunda bireylerin varoluşlarına yönelik bu olumlu algıları zedelenmektedir. Bu dört temel ihtiyaç farklı dışlama türlerinden farklı ölçülerde etkilenmekte ve hangi ihtiyacın daha çok tehdit edildiğine bağlı olarak farklı davranışsal, duygusal ve 
bilişsel tepkiler doğmaktadır. Pek çok araştırmada, katılımcıların bu dört ihtiyacının dışlanma tehdidi karşısında olumsuz etkilendiği bildirilmiştir (örn., Abrams ve diğer., 2011; Chernyak ve Zayas, 2010; Kaya, 2012; Williams ve diğer., 2002; Zadro, Boland ve Richardson, 2006; Zadro, Williams ve Richardson, 2004).

\section{Sonuç}

Sosyal dişlanma, pek çok biçimiyle insan sosyalliğinin merkezinde sayılabilecek bir olgu olarak karşımıza çıkmaktadır. Hemen her bireyin zaman zaman yaşadığı dışlanma deneyimi fiziksel ve psikolojik iyi olma halini önemli düzeyde etkilemektedir (Wesselmann ve Williams, 2017). Bu yüzden, özellikle 20. yüzyılın ikinci yarısından itibaren sosyal dışlanma olgusuna yönelik bilimsel ilgi giderek artmış, bugün geldiğimiz noktada çok sayıda deneysel bulgu ortaya konmuştur. Sosyal dışlanmanın nedenleri ve sonuçlarına dair edinilecek yeni bilgiler, kişiler ve gruplar arası ilişkilerde kendini gösteren sorunların daha iyi anlaşılmasını da sağlayacaktır.

\section{Kaynakça}

Abayhan, Y., Yavuz, H., Ceylan, S., Kaya, A.G., Sahin, D., \& Aydın, O. (2009). Brainstorming as a paradigm for studying ostracism: Experiments with brainstorming and cyberball paradigms. Oral presentation at the 11th European Congress of Psychology, Oslo, Norway.

Abrams, D., Weick, M., Thomas, D., Colbe, H., \& Franklin, K.M. (2011). On-line ostracism affects children differently from adolescents and adults. British Journal of Experimental Psychology, 29, 110-123.

Aydin, N., Graupmann, V., Fischer, J., Frey, D., \& Fischer, P. (2011). My role is my castle - The appeal of family roles after experiencing social exclusion. Journal of Experimental Social Psychology, 47, 981-986.

Balliet, D., \& Ferris, D.L. (2013). Ostracism and prosocial behavior: A social dilemma perspective. Organizational Behavior and Human Decision Processes, 120, 298-308.

Baumeister, R.F., \& DeWall, C.N. (2005). The inner dimension of social exclusion. In K.D. Williams, J.P. Forgas, \& W. von Hippel (Eds.), The Social Outcast: Ostracism, Social Exclusion, Rejection, and Bullying (pp. 53-73). New York: Psychology Press.

Baumeister, R.F., \& Leary, M.R. (1995). The need to belong: Desire for interpersonal attachments as a fundamental human motivation. Psychological Bulletin, 117(3), 491-529.

Baumeister, R.F., Brewer, L.E., Tice, D.M., \& Twenge, J.M. (2007). Thwarting the need to belong: Understanding the interpersonal and inner effects of social exclusion. Social and Personality Psychology Compass, 1(1), 506-520.

Baumeister, R.F., DeWall, C.N., Ciarocco, N.J., \& Twenge, J.M. (2005). Social exclusion impairs self-regulation. Journal of Personality and Social Psychology, 88, 589-604.

Baumeister, R.F., Twenge, J.M., \& Nuss, C.K. (2002). Effects of social exclusion on cognitive processes: Anticipated aloneness reduces intelligent thought. Journal of Personality and Social Psychology, 83, 817-827. 
Benenson, J.F., Hodgson, L., Heath, S., \& Welch, P.J. (2008). Human sexual differences in the use of social ostracism as a competitive tactic. International Journal of Primatology, 29, 10191035.

Benenson, J.F., Markovits, H., Thompson, M.E., \& Wrangham, R.W. (2011). Under threat of social exclusion, females exclude more than males. Psychological Science, 22(4), 538-544.

Bernstein, M.J., \& Claypool, H.M. (2011). Social exclusion and pain sensitivity: Why exclusion sometimes hurts and sometimes numbs. Personality and Social Psychology Bulletin, 38(2), 185196.

Bernstein, M.J., Sacco, D.F., Brown, C.M., Young, S.G., \& Claypool, H.M. (2010). A preference for genuine smiles following social exclusion. Journal of Experimental Psychology, 46, 196-199.

Bilgin, N. (2003). Sosyal Psikoloji Sözlüğ̈̈̈. Ankara: Bağlam Yayınları.

Boesch, C. (2012). The ecology and evolution of social behavior and cognition in primates. In T.K. Shackelford \& J. Vonk (Eds.), Oxford Handbook of Comparative Evolutionary Psychology (pp. 486-503). New York: Oxford University Press.

Bolling, D.Z., Pelphrey, K.A., \& Wyk, B.C.V. (2016). Unlike adults, children and adolescents show predominantly increased neural activation to social exclusion by members of the opposite gender. Social Neuroscience, 11(5), 475-486.

Bozin, M.A., \& Yoder, J.D. (2008). Social status, not gender alone, is implicated in different reactions by women and men to social ostracism. Sex Roles, 58, 713-720.

Buckner, J.D., DeWall, C.N., Schmidt, N.B., Maner, J.K. (2010). A tale of two threats: Social anxiety and attention to social threat as a function of social exclusion and non-exclusion threats. Cognitive Therapy and Research, 34, 449-455.

Chernyak, N., \& Zayas, V. (2010). Being excluded by one means being excluded by all: Perceiving exclusion from inclusive others during one-person social exclusion. Journal of Experimental Social Psychology, 46, 582-585.

Coyne, S.M., Gundersen, N., Nelson, D.A., \& Stockdale, L. (2011). Adolescents' prosocial responses to ostracism: An experimental study. The Journal of Social Psychology, 151(5), 657661.

Craighead, W.E., Kimball, W.H., \& Rehak, P.J. (1979). Mood changes, physiological responses, and self-statements during social rejection imagery. Journal of Consulting and Clinical Psychology, 47, 385-396.

DeWall, C.N., \& Baumeister, R.F. (2006). Alone but feeling no pain: Effects of social exclusion on physical pain tolerance and pain threshold, affective forecasting, and interpersonal empathy. Journal of Personality and Social Psychology, 91, 1-15.

DeWall, C.N., Maner, J.K., \& Rouby, D.A. (2009). Social exclusion and early-stage interpersonal perception: Selective attention to signs of acceptance. Journal of Personality and Social Psychology, 96, 729-741.

DeWall, C.N., Twenge, J.M., Gitter, S.A., \& Baumeister, R.F. (2009). It's the thought that counts: The role of hostile cognition in shaping aggressive responses to social exclusion. Journal of Personality and Social Psychology, 96, 45-59. 
Dittes, J.E. (1959). Attractiveness of group as function of self-esteem and acceptance by group. Journal of Abnormal and Social Psychology, 59, 77-82.

Donate, A.P.G., Marques, L.M., Lapenta, O.M., Asthana, M.K., Amodio, D., \& Boggio, P.S. (2017). Ostracism via virtual chat room - Effects on basic needs, anger and pain. PLoS ONE, 12(9): e0184215.

Dunbar, R.I.M. (2007). The social brain hypothesis and its relevance to social psychology. In J.P. Forgas, M.G. Haselton, \& W. von Hippel (Eds.), Evolution and the Social Mind: Evolutionary Psychology and Social Cognition (pp. 21-31). New York: Psychology Press.

Eisenberger, N.I., Lieberman, M.D., \& Williams, K.D. (2003). Does rejection hurt? An fMRI study of social exclusion. Science, 302, 290-292.

Fenigstein, A. (1979). Self-consciousness, self attention, and social interaction. Journal of Personality and Social Psychology, 37, 75-86.

Forsdyke, F. (2005). Exile, Ostracism, and Democracy: The Politics of Expulsion in Ancient Greece. NJ: Princeton University Press.

Gardner, W.L., Pickett, C.L., \& Brewer, M.B. (2000). Social exclusion and selective memory: How the need to belong influences memory for social events. Personality and Social Psychology Bulletin, 26, 486-496.

Geller, D.M., Goodstein, L., Silver, M., \& Sternberg, W.C. (1974). On being ignored: The effects of violation of implicit rules of social interaction. Sociometry, 37, 541-556.

Gerber, J., \& Wheeler, L. (2009). On being rejected: A meta-analysis of experimental research on rejection. Perspectives on Psychological Science, 4(5), 468-488.

Gonsalkorale, K., \& Williams, K.D. (2007). The KKK won't let me play: Ostracism even by a despised outgroup hurts. European Journal of Social Psychology, 37, 1176-1186.

Goodall, J. (1986). Social rejection exclusion and shunning among the Gombe chimpanzees. Ethology and Sociobiology, 7, 227-239.

Grippo, A.J. (2009). Mechanisms underlying altered mood and cardiovascular dysfunction: The value of neurobiological and behavioral research with animal models. Neuroscience and Biobehavioral Reviews, 33, 171-180.

Hartgerink, C.H., van Beest, I., Wicherts, J.M., \& Williams, K.D. (2015). The ordinal effects of ostracism: A meta-analysis of 120 Cyberball studies. PloS One, 10, e0127002.

Haselton, M.G., \& Buss, D.M. (2000). Error management theory: A new perspective on biases cross-sex mind reading. Journal of Personality and Social Psychology, 78, 81-91.

Hawkley, L.C., Williams, K.D., \& Cacioppo, J.T. (2011). Responses to ostracism across adulthood. Social Cognitive \& Affective Neuroscience, 6, 234-243.

Hess, Y.D., \& Pickett, C.L. (2010). Social exclusion and self- versus other-awareness. Journal of Experimental Social Psychology, 46, 453-456.

Ijzerman, H., Gallucci, M., Pouw, W.T.J.L., Weßberger, S.C., Van Doesum, N.J., \& Williams, K.D. (2012). Cold-blooded loneliness: Social exclusion leads to lower skin temperatures. Acta Psychologica, 140, 283-288. 
Jackson, J.M., \& Saltzstein, H.D. (1957). The effect of person-group relationships on conformity processes. Journal of Abnormal and Social Psychology, 57, 17-24.

Kaya, A.G., Yavuz, H., Abayhan, Y., Şahin, D., \& Aydın, O. (2008). Benlik değerinin psikolojik dışlanma üzerindeki etkisi. Sözlü bildiri, 15. Ulusal Psikoloji Kongresi, İstanbul, Türkiye.

Kerr, N.L., \& Levine, J.M. (2008). The detection of social exclusion: Evolution and beyond. Group Dynamics: Theory, Research, and Practice, 12(1), 39-52.

Lakin, J.L., \& Chartrand, T.L. (2005). Exclusion and no nonconscious behavioral mimicry. In K.D. Williams, J.P. Forgas, \& W. von Hippel (Eds.), The Social Outcast: Ostracism, Social Exclusion, Rejection and Bullying (pp. 279-295). New York: Psychology Press.

Lang, M.L. (1990). The Athenian Agora: Ostraka. NJ: American School of Classical Studies.

Leary, M.R. (1999). Making sense of self-esteem. Current Directions in Psychological Science, 8, 32-35.

Leary, M.R. (2005). Varieties of interpersonal rejection. In K.D. Williams, J.P. Forgas, \& W. von Hippel (Eds.), The Social Outcast: Ostracism, Social Exclusion, Rejection and Bullying (pp. 3551). New York: Psychology Press.

Leary, M.R., \& Baumeister, R.F. (2000). The nature and function of self-esteem: Sociometer theory. In M.P. Zanna (Ed.), Advances in Experimental Social Psychology, Vol. 32 (pp. 1-62). San Diego, CA: Academic Press.

Leary, M.R., Kowalski, R.M., Smith, L., \& Philips, S. (2003). Teasing, rejection, and violence: case studies of the school shootings. Aggressive Behavior, 29, 202-214.

Leary, M.R., Tambor, E.S., Terdal, S.K., \& Downs, D.L. (1995). Self-esteem as an interpersonal monitor: The sociometer hypothesis. Journal of Personality and Social Psychology, 68, 518-530.

Leary, M.R., Twenge, J.M., \& Quinlivan, E. (2006). Interpersonal rejection as a determinant of anger and aggression. Personality and Social Psychology Review, 10, 111-132.

MacDonald, G., \& Leary, M.R. (2005). Why does social exclusion hurt? The relationship between social and physical pain. Psychological Bulletin, 131, 202-223.

MacDonald, G., Kingsbury, R., \& Shaw, S. (2005). Adding insult to injury: Social pain theory and response to social exclusion. In K.D. Williams, J.P. Forgas, \& W. von Hippel (Eds.), The Social Outcast: Ostracism, Social Exclusion, Rejection and Bullying (pp. 77-90). New York: Psychology Press.

Maner, J.K., DeWall, C.N., Baumeister, R.F., \& Schaller, M. (2007). Does social exclusion motivate interpersonal reconnection? Resolving the "porcupine problem. Journal of Personality and Social Psychology, 92, 42-55.

McDonald, M.M., \& Donnellan, M.B. (2012). Is ostracism a strong situation? The influence of personality in reactions to rejection. Journal of Research in Personality, 46, 614-618.

McGuire, M.T., \& Raleigh, M.J. (1986). Behavioral and physiological correlates of ostracism. Ethology and Sociobiology, 7, 187-200.

Mendes, W.B., Major, B., McCoy, S., \& Blascovich, J. (2008). How attributional ambiguity shapes physiological and emotional responses to social rejection and acceptance. Journal of Personality and Social Psychology, 94, 278-291. 
Moor, B.G, Crone, E.A., \& van der Molen, M.W. (2010). The Heartbrake of social rejection: Heart rate deceleration in response to unexpected peer rejection. Psychological Science, 21(9), 1326-1333.

Moor, B.G., Güroğlu, B., Op de Macks, Z.A., Rombouts, S.A.R.B., van der Molen, M.W., \& Crone, E.A. (2012). Social exclusion and punishment of excluders: Neural correlates and developmental trajectories. NeuroImage, 59, 708-717.

Nesdale, D., \& Lambert, A. (2008). Effects of experimentally induced peer-group rejection on children's risk taking behaviour. European Journal of Developmental Psychology, 5(1), 19-38.

Oaten, M., Williams, K.D., Jones, A., \& Zadro, L. (2008). The effects of ostracism on selfregulation in the socially anxious. Journal of Social and Clinical Psychology, 27, 471-504.

Over, H., \& Carpenter, M. (2009). Priming third-party ostracism increases affiliative imitation in children. Developmental Science, 12(3), F1-F8.

Pickett, C., Gardner, W.L., \& Knowles, M.L. (2004). Getting a cue: The need to belong influences attention to subtle social cues. Personality and Social Psychology Bulletin, 30, 10951107.

Pickett, C.L., \& Gardner, W.L. (2005). The social monitoring system: Enhanced sensitivity to social clues as an adaptive response to social exclusion. In K.D. Williams, J.P. Forgas, \& W. Von Hippel (Eds.), The Social Outcast: Ostracism, Social Exclusion, Rejection, and Bullying (pp. 213-226). New York: Psychology Press.

Riva, P., \& Eck, J. (2016). The many faces of social exclusion. In P. Riva \& J. Eck (Eds.), Social Exclusion: Psychological Approaches to Understanding and Reducing Its Impact (pp. ix-xv). Cham, Switzerland: Springer International.

Riva, P., Wirth, J.H., \& Williams, K.D. (2011). The consequences of pain: The social and physical pain overlap on psychological responses. European Journal of Social Psychology, 41, 681-687.

Sacco, D.F., Wirth, J.H., Hugenberg, K., Chen, Z., \& Williams, K.D. (2011). The world in black and white: Ostracism enhances the categorical perception of social information. Journal of Experimental Social Psychology, 47, 836-842.

Sacco, D.F., Young, S.G., Brown, C.M., Bernstein, M.J., \& Hugenberg, K. (2012). Social exclusion and female mating behavior: Rejected women show strategic enhancement of short-term mating interest. Evolutionary Psychology, 10(3), 573-587.

Seidel, E.M., Silani, G., Metzler, H., Thaler, H., Lamm, C., Gur, R.C., Kryspin-Exner, I., Habel, U., \& Derntl, B. (2013). The impact of social exclusion vs. inclusion on subjective and hormonal reactions in females and males. Psychoneuroendocrinology, 38, 2925-2932.

Schachter, S. (1951). Deviation, rejection, and communication. Journal of Abnormal and Social Psychology, 46, 190-207.

Schaller, M., \& Neuberg, S.L. (2008). Intergroup prejudices and intergroup conflicts. In C. Crawford \& D. Krebs (Eds.), Foundations of Evolutionary Psychology (pp. 401-415). New York: Taylor \& Francis Group, LLC.

Sleegers, W.W.A., Proulx, T., \& van Beest, I. (2017). The social pain of Cyberball: Decreased pupillary reactivity to exclusion cues. Journal of Experimental Social Psychology, 69, 187-200. 
Smith, A., \& Williams, K.D. (2004). R u there? Ostracism by cellphone text messages. Group Dynamics: Theory, Research, and Practice, 8(4), 291-301.

Snoek, J.D. (1962). Some effects of rejection upon attraction to a group. Journal of Abnormal and Social Psychology, 64, 175-182.

Sommer, K.L., \& Baumeister, R.F. (2002). Self-evaluation, persistence, and performance following implicit rejection: The role of trait self-esteem. Personality and Social Psychology Bulletin, 28(7), 926-938.

Spoor, J.R., \& Williams, K.D. (2007). The evolution of an ostracism detection system. In J.P. Forgas, M.G. Haselton, \& W. von Hippel (Eds.), Evolution and the Social Mind: Evolutionary Psychology and Social Cognition (pp. 279-292). New York: Psychology Press.

Stillman, T.F., Baumeister, R.F., Lambert, N.M., Crescioni, A.W., DeWall, C.N., \& Fincham, F.D. (2009). Alone and without purpose: Life loses meaning following social exclusion. Journal of Experimental Social Psychology, 45, 686-694.

Tooby, J., \& Cosmides, L. (2005). Conceptual foundations of evolutionary psychology. In D.M. Buss (Ed.), The Handbook of Evolutionary Psychology (pp. 5-68). New Jersey: John Wiley \& Sons.

Twenge, J.M., Baumeister, R.F., DeWall, C.N., Ciarocco, N.J., \& Bartels, J.M. (2007). Social exclusion decreases prosocial behavior. Journal of Personality and Social Psychology, 92, 56-66.

Twenge, J.M., Baumeister, R.F., Tice D.M., \& Stucke, T.S. (2001). If you can't join them, beat them: effects of social exclusion on aggressive behavior. Journal of Personality and Social Psychology, 81, 1058-1069.

Twenge, J.M., Catanese, K.R., \& Baumeister, R.F. (2002). Social exclusion causes self-defeating behavior. Journal of Personality and Social Psychology, 83, 606-615.

Van Beest, I., Williams, K.D., \& Van Dijk, E. (2011). Cyberbomb: Effects of being ostracized from a death game. Group Processes \& Intergroup Relations, 14(4), 581-596.

Weik, U., Maroof, P., Zöller, C., \& Deinzer, R. (2010). Pre-experience of social exclusion suppresses cortisol response to psychosocial stress in women but not in men. Hormones and Behavior, 58, 891-897.

Wesselmann, E.D., Grzybowski, M.R., Steakley-Freeman, D.M., DeSouza, E.R., Nezlek, J.B., \& Williams, K.D. (2016). Social exclusion in everyday life. In P. Riva \& J. Eck (Eds.), Social Exclusion: Psychological Approaches to Understanding and Reducing Its Impact (pp. 3-23). Cham, Switzerland: Springer International.

Wesselmann, E.D., Nairne, J.S., \& Williams, K.D. (2012). An evolutionary social psychological approach to studying the effects of ostracism. Journal of Social, Evolutionary, and Cultural Psychology, 6(3), 309-328.

Wesselmann, E.D., \& Williams, K.D. (2017). Social life and social death: Inclusion, ostracism, and rejection in groups. Group Processes \& Intergroup Relations, 20(5), 693-706.

Wesselmann, E.D., Wirth, J.H., Pryor, J.B., Reeder, G.D., \& Williams, K.D. (2013). When do we ostracize? Social Psychological and Personality Science, 4(1), 108-115. 
Wike, T.L., \& Fraser, M.W. (2009). School shootings: Making sense of the senseless. Aggression and Violent Behavior, 14, 162-169.

Williams, K.D. (2001). Ostracism: The power of silence. NY: Guilford.

Williams, K.D. (2007). Ostracism. Annual Review of Psychology, 58, 425-452.

Williams, K.D., \& Jarvis, B. (2006). Cyberball: A program for use in research on ostracism and interpersonal acceptance. Behavior Research Methods, Instruments, and Computers, 38, 174-180.

Williams, K.D., \& Nida, S.A. (2011). Ostracism: Consequences and coping. Current Directions in Psychological Science, 20(2), 71-75.

Williams, K.D., \& Zadro, L. (2001). Ostracism: On being ignored, excluded, and rejected. In M.R. Leary (Ed.), Interpersonal Rejection (pp. 21-55). New York: Oxford University Press.

Williams, K.D., \& Zadro, L. (2005). Ostracism: The indiscriminate early detection system. In K.D. Williams, J.P. Forgas, \& W. von Hippel (Eds.), The Social Outcast: Ostracism, Social Exclusion, Rejection and Bullying (pp. 19-34). New York: Psychology Press.

Williams, K.D., Cheung, C.K.T., \& Choi, W. (2000). CyberOstracism: Effects of being ignored over the internet. Journal of Personality and Social Psychology, 79, 748-762.

Williams, K.D., Forgas, J.P., von Hippel, W., \& Zadro, L. (2005). The social outcast: An overview. In K.D. Williams, J.P. Forgas, \& W. von Hippel (Eds.), The Social Outcast: Ostracism, Social Exclusion, Rejection and Bullying (pp. 1-16). New York: Psychology Press.

Williams, K.D., Govan, C.L., Croker, V., Tynan, D., Cruickshank, M., \& Lam, A. (2002). Investigations into differences between social- and cyberostracism. Group Dynamics: Theory, Research, and Practice, 6(1), 65-77.

Wirth, J.H. (2016). Methods for investigating social exclusion. In P. Riva \& J. Eck (Eds.), Social Exclusion: Psychological Approaches to Understanding and Reducing Its Impact (pp. 25-51). Cham, Switzerland: Springer International.

Wolf, W., Levordashka, A., Ruff, J.R., Kraaijeveld, S., Lueckmann, J.M., \& Williams, K.D. (2015). Ostracism online: A social media ostracism paradigm. Behavior Research Methods, 47, 361-373.

Zadro, L., Boland, C., \& Richardson, R. (2006). How long does it last? The persistence of the effects of ostracism in the socially anxious. Journal of Experimental Social Psychology, 42, 692697.

Zadro, L., Williams, K.D., \& Richardson, R. (2004). How low can you go? Ostracism by a computer is sufficient to lower self-reported levels of belonging, control, self-esteem, and meaningful existence. Journal of Experimental Social Psychology, 40, 560-567.

Zhong, Chen-Bo \& Leonardelli, G.J. (2008). Cold and lonely: Does social exclusion literally feel cold? Psychological Science, 19, 838-842. 